\title{
Oparzenia wieku dziecięcego w regionie Pomorza Zachodniego w latach 80. XX wieku i obecnie*
}

\section{Burns and scalds in children of the Western Pomerania region in the 1980s and today}

\author{
Beata Brodzińska ${ }^{凶}$ \\ Pomorski Uniwersytet Medyczny w Szczecinie, Zakład Pediatrii i Pielęgniarstwa Pediatrycznego, ul. Żołnierska 48, 71-210 Szczecin \\ $\bowtie$ beata.brod@wp.pl
}

\begin{abstract}
Introduction: Burns in children are among the most severe injuries, requiring fast, multidisciplinary treatment.

The aim of the study was to compare the epidemiology, aetiology and severity of burns, methods and results of treatment, and to characterise trends in the care of children from the region of Western Pomerania in Poland hospitalized because of burns. Materials and methods: The medical records of 1,230 patients were analyzed. They were divided into two groups: 710 children treated in 1985-1988 (4 years) and 520 children treated in 2006-2010 (5 years). The analysis included demographic data, aetiology, the type of first aid provided, clinical evaluation of the scalded surface, and the method of treatment.

Results: In both groups the body burns most often occurred in the group of children between 1-2 years of age, always twice as
\end{abstract}

often in boys. The cause of body burns was mostly hot fluid, both in the 1980 s and today. The average length of hospitalization of children with severe burns was 31 days in the 1980 s vs. 14 days today. Formerly conservative treatment was preferred, while today surgical treatment is implemented faster and more often. Conclusion: In Western Pomerania the incidence of hospitalization of children with burns decreased twofold. The most commonly treated children are aged 1-2 years, boys - twice as often; a high percentage of them are infants. The most common cause of burns in infants and young children remains hot fluid, and in the group of older children flames as well. In relation to the 1980 s, the current treatment methods result in a shorter hospital stay.

Keywords: burn; child; hot fluid; skin graft.

\begin{abstract}
ABSTRAKT
Wstęp: Oparzenia u dzieci należą do jednych z najcięższych urazów wymagających szybkiego i wielospecjalistycznego leczenia. Celem pracy była analiza porównawcza epidemiologii, etiologii, ciężkości oparzenia, sposobów i wyników leczenia oraz charakterystyka zmian kierunków opieki nad dziećmi hospitalizowanymi z powodu oparzenia, zamieszkującymi region Pomorza Zachodniego.

Materiały i metody: Analizie poddano dokumentację medyczną 1230 pacjentów. Podzielono ich na dwie grupy: 710 dzieci leczonych w latach 1985-1988 (4 lata) i 520 dzieci leczonych w latach 2006-2010 (5 lat). Analiza obejmowała dane demograficzne, etiologiczne, rodzaj udzielonej pierwszej pomocy, ocenę kliniczną powierzchni oparzonej oraz sposób zastosowanego leczenia. Wyniki: W obu badanych grupach do oparzeń ciała najczęściej dochodziło u dzieci pomiędzy 1. a 2. r.ż., zawsze 2-krotnie częściej
\end{abstract}

u chłopców. Zarówno w latach 80. XX w., jak i obecnie przyczyną najczęściej był gorący płyn. W latach 80. XX w. średnia długość hospitalizacji dzieci z oparzeniami ciężkimi wynosiła 31 dni, obecnie - 14 dni. Dawniej preferowano zachowawczy sposób leczenia, obecnie częściej i szybciej stosowano leczenie operacyjne.

Wnioski: Na Pomorzu Zachodnim 2-krotnie obniżyła się częstość hospitalizacji oparzonych dzieci. Najczęściej były i są leczone dzieci w wieku od 1. r.ż. do 2 lat, 2-krotnie częściej chłopcy; wysoki odsetek stanowią niemowlęta. Najczęstszą przyczyną oparzeń u niemowląt i dzieci młodszych pozostaje gorący płyn, a u dzieci starszych także płomień. W stosunku do lat 80. XX w. obecne metody leczenia gwarantują krótszy czas hospitalizacji. Słowa kluczowe: oparzenie; dziecko; gorący płyn; przeszczep skóry.

\section{WSTĘP}

Na całym świecie oparzenia są dużym problemem zdrowia publicznego zarówno w aspekcie następstw fizycznych, psychologicznych, jak i ekonomicznych. Związany z oparzeniami ból, oszpecenie i deformacje ciała oraz wstrząs pourazowy wymagają długotrwałego specjalistycznego leczenia oraz rehabilitacji [1]. Zaburzenia ogólnoustrojowe, określane mianem choroby oparzeniowej, zagrażają bezpośrednio życiu dziecka. Wymagają wdrożenia wysokospecjalistycznego, intensywnego leczenia ogólnego i miejscowego.

Oparzenia najczęściej dotyczą dzieci najmłodszych, do 3.-5. r.ż. [2]. Są zwykle następstwem braku należytej opieki nad nimi ze strony osób dorosłych. Małe dzieci są ciekawe świata,

* Zwięzła wersja rozprawy doktorskiej przyjętej przez Radę Wydziału Nauk o Zdrowiu Pomorskiego Uniwersytetu Medycznego w Szczecinie. Promotor: prof. dr hab. n. med. Grażyna Czaja-Bulsa. Oryginał obejmuje: 138 stron, 52 ryciny, 14 tabel i 258 pozycji piśmiennictwa. 
naturalnie ruchliwe, nie rozumieją zagrożeń, poznają nowe otoczenie poprzez dotyk, co sprawia, że łatwo ulegają oparzeniom [3]. Najczęściej, bo w 80\% oparzenia u dzieci są oparzeniami stopnia lekkiego lub średniego, pozostałe $20 \%$ to oparzenia ciężkie [4]. W populacji dziecięcej stanowią trzecią przyczynę zgonów, za wypadkami komunikacyjnymi i utonięciami.

W ciągu ostatnich lat uzyskano znaczny postęp w leczeniu oparzeń. Jest on następstwem nie tylko szybkiego zamykania rany oparzeniowej, co zapobiega rozwojowi zakażenia, ale także wprowadzenia resuscytacji płynowej i leczenia żywieniowego oraz postępowania zapobiegającego wystąpieniu zespołu ostrej niewydolności oddechowej. Efektem takiego postępowania w krajach wysoko rozwiniętych jest znaczny spadek śmiertelności z powodu tychże urazów. Jednak w krajach rozwijających się stanowią one nadal duży problem, a liczba zgonów, zwłaszcza wśród dzieci, jest ciągle duża [5].

Celem badania była: 1. Ocena epidemiologii i etiologii oparzeń u dzieci zamieszkujących region Pomorza Zachodniego w latach 80. XX w. i obecnie. 2. Ocena sposobu udzielania pierwszej pomocy przedmedycznej i rodzaju transportu. 3. Ocena stopnia zmian organizacji leczenia dzieci oparzonych z Pomorza Zachodniego oraz porównanie metod i czasu leczenia szpitalnego.

Celem utylitarnym pracy była charakterystyka kierunków zmian opieki nad dziećmi z oparzeniem skóry zamieszkującymi w ciągu ostatnich 25 lat region Pomorza Zachodniego.

\section{MATERIAtY I METODY}

Materiał obejmuje retrospektywną ocenę dokumentacji medycznej 1230 pacjentów hospitalizowanych z powodu oparzenia powłok. Do badania włączono dzieci obojga płci w wieku od 28. doby życia do 17 lat, leczonych z powodu oparzenia. Spośród wszystkich pacjentów wyodrębniono 2 grupy. Grupę pierwszą (grupa I) stanowiło 710 dzieci leczonych w latach 80. XX w. przez okres 4 lat (1985-1988), a grupę drugą (grupa II) 520 pacjentów leczonych w pierwszych latach XXI w. przez okres 5 lat (2006-2010). Analiza retrospektywna dokumentacji medycznej oparzonych dzieci obejmowała informacje zawarte w historiach chorób.

W ocenie uwzględniono następujące czynniki:

1. Demograficzne:

- wiek dziecka w momencie wypadku; dzieci podzielono na 6 grup: do 1. r.ż., 1,1.-2. r.ż., 2,1.-3. r.ż., 3,1.-7. r.ż., 7,1.-11. r.ż., 11,1.-17. r.ż.,

- płeć,

- miejsce zamieszkania (Szczecin, mniejsze miasta województwa zachodniopomorskiego, wieś).

2. Etiologiczne: gorąca ciecz, płomień, kontaktowe, elektryczne, chemiczne.

3. Ocenę kliniczną powierzchni oparzonej:

- makroskopowa ocena głębokości rany na podstawie uszkodzenia kolejnych warstw skóry za pomocą skali opisanej przez Arzta i Reisa,

- ocena rozległości oparzenia na podstawie modyfikowanych tablic Lunda i Browdera,
- zajęcie okolic wstrząsorodnych: głowa, szyja, dłonie, stopy, doły łokciowe, podkolanowe,

- klasyfikacja ogólna ciężkości oparzenia na podstawie ABA.

4. Rodzaj udzielonej pierwszej pomocy.

5. Leczenie szpitalne:

- długość hospitalizacji, obliczaną za pomocą różnicy w liczbie dni od daty przyjęcia dziecka do szpitala do daty wypisu,

- zastosowanie leczenia zachowawczego i/lub operacyjnego,

- czas wykonania przeszczepów skóry, obliczany za pomocą różnicy w liczbie dni od momentu urazu do momentu zabiegu operacyjnego,

- częstość i rodzaj powikłań występujących w trakcie hospitalizacji.

Wszystkie uzyskane dane zarchiwizowano w elektronicznej bazie danych programu Excel i poddano analizie statystycznej testem $\chi^{2}$ Pearsona, dokładnym testem Fishera oraz testem $\mathrm{R}$ rang Spearmana. Za istotne statystycznie uznano wyniki analizy przy $\mathrm{p}<0,05$.

\section{WYNIKI}

\section{Dane demograficzne}

W latach 1985-1988 corocznie w regionie Pomorza Zachodniego hospitalizowano średnio 177 (167-183) dzieci. W latach 2006-2010 corocznie liczba ich była średnio 1,7-krotnie mniejsza i wyniosła 104 (90-115) dzieci w ciągu roku. W latach 1985-1988 w regionie zamieszkiwało średnio 310 277,5 dzieci, a z powodu oparzeń rocznie hospitalizowano średnio 0,057\% dzieci. W latach 2006-2010 zamieszkiwało średnio 347812 dzieci, a z powodu oparzeń rocznie hospitalizowano średnio $0,029 \%$ dzieci.

W latach 1985-1988 na Pomorzu Zachodnim oparzeniom skóry najczęściej ulegały dzieci wiejskie (38\%). Obecnie w tej grupie dzieci występują one najrzadziej (38\% vs 28\%; $\mathrm{p}=0,0005)$. W ciągu lat wzrosła częstość oparzeń skóry wśród dzieci mieszkających w Szczecinie (32\% vs 37\%; NS).

W obu badanych okresach czasu najczęściej hospitalizowano dzieci pomiędzy 1. a 2. r.ż. ( $47 \%$ vs $51 \%$; NS) oraz - 3-krotnie rzadziej niemowlęta (15\% vs 17\%; NS) - rycina 1. Dzieci do 3. r.ż.

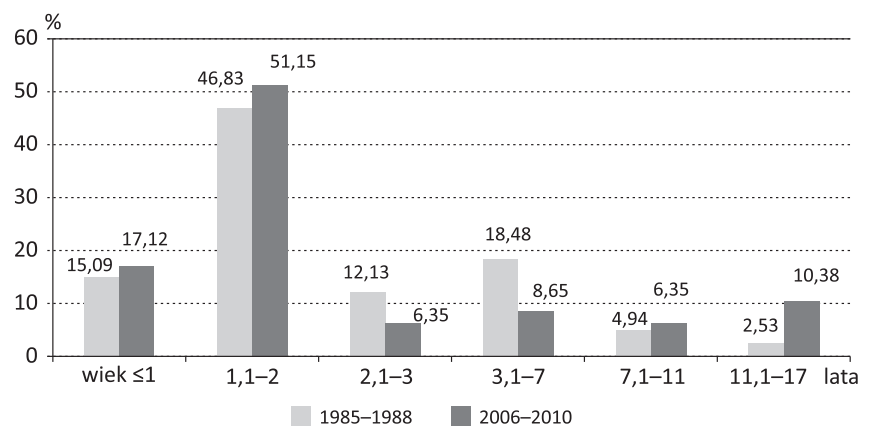

RYCINA 1. Wiek dzieci hospitalizowanych z powodu oparzenia skóry w badanych okresach czasu 
zawsze stanowiły $74 \%$ hospitalizowanych. Dzieci starsze hospitalizowano rzadko. Na przestrzeni 25 lat stwierdzono jednak 4-krotny wzrost częstości hospitalizacji dzieci najstarszych, w wieku 11,1-17 lat $(2,5 \%$ vs $10 \%, \mathrm{p}<0,001)$.

W obu badanych grupach stosunek dziewcząt do chłopców był taki sam ( $p=0,557) ; 1,7$-krotnie przeważali chłopcy. Najwyższą przewagę chłopców obserwowano w grupie dzieci najstarszych, w której stanowili oni 94\% w latach 1985-1988 i 74\% w latach 2006-2010.

\section{Etiologia oparzeń u dzieci}

W latach 1985-1988 najczęstszą przyczyną oparzeń u dzieci do 11. r.ż. był gorący płyn ( $\mathrm{p}<0,001)$ - rycina 2. Do 3. r.ż. odsetek dzieci oparzonych gorącym płynem wynosił 90-95\%. U dzieci starszych systematycznie malał, u najstarszych (11-17 lat) wynosił 33\%. Odwrotną tendencję obserwowano dla oparzenia wywołanego przez płomień - po 2. r.ż. odsetek oparzonych dzieci wolno wzrastał, po 11. r.ż. była to najczęstsza przyczyna oparzeń (56\%). Inne środki rzadko wywoływały oparzenia skóry - najczęściej u dzieci po 11. r.ż. (6\%).

W latach 2006-2010 najczęstszą przyczyną oparzeń we wszystkich grupach wiekowych był także gorący płyn (ryc. 3). Do 3. r.ż. był on przyczyną 90-97\% oparzeń. Po 3. r.ż. obserwowano spadek częstości oparzeń skóry wywołanych przez gorący płyn; u dzieci najstarszych odpowiadał on za 35\% oparzeń. Drugą co do częstości przyczyną oparzeń był płomień.

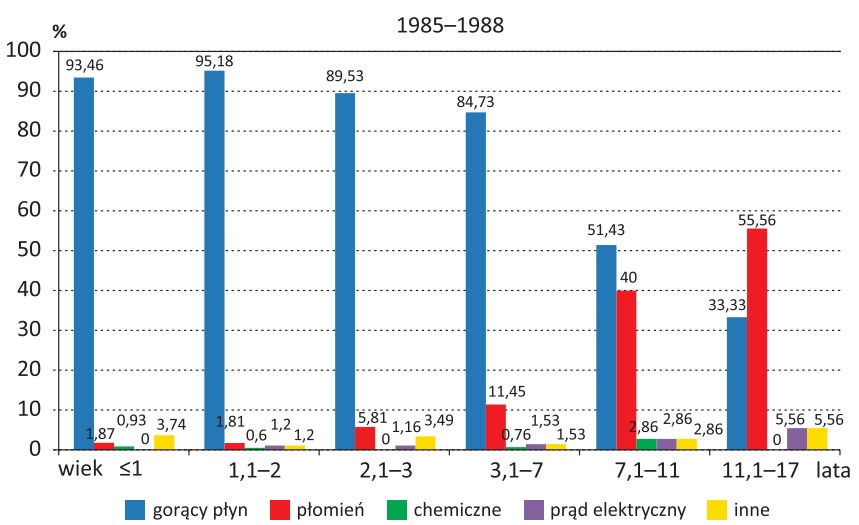

RYCINA 2. Przyczyny oparzeń w zależności od wieku dzieci hospitalizowanych w latach 1985-1988

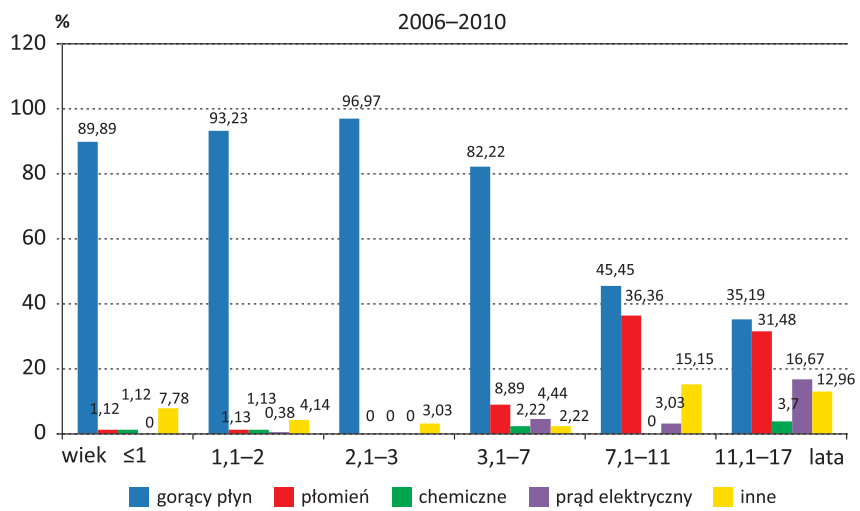

RYCINA 3. Przyczyny oparzeń w zależności od wieku dzieci hospitalizowanych w latach 2006-2010
Częstość tych oparzeń wzrastała po 3. r.ż. W wieku 3,1-7 lat płomień odpowiadał za $9 \%$ oparzeń, a u dzieci starszych za $1 / 3$. Oparzenia prądem elektrycznym występowały przede wszystkim u dzieci najstarszych, u których odpowiadały za 17\% oparzeń. Oparzenia tzw. innymi środkami występowały przede wszystkim u niemowląt (8\%) oraz u dzieci po 7. r.ż. (15\% i 13\%). W każdym z wydzielonych przedziałów wiekowych środki chemiczne były najrzadszą przyczyną oparzeń skóry.

Nie stwierdzono różnic istotnych statystycznie w częstości przyczyn, które spowodowały oparzenia skóry w wydzielonych przedziałach wiekowych u dzieci hospitalizowanych w latach 1985-1988 oraz 2006-2010. Jedyną istotną różnicą była wyższa częstość oparzeń wywołanych przez tzw. inne środki, którą stwierdzono u dzieci w wieku 1,1-2 lat hospitalizowanych w latach $2006-2010(1,2 \%$ vs $4,1 \%$; $p=0,022)$.

\section{Ocena kliniczna powierzchni oparzonej}

Oparzenia do 10\% całkowitej powierzchni ciała (total body surface area - TBSA) występowały u 74\% dzieci z grupy I, natomiast u dzieci z grupy II w 53\% (p < 0,001). Powierzchnia oparzenia do $20 \%$ TBSA występowała u ok. $20 \%$ dzieci z grupy I i $34 \%$ z grupy II $(p=0,0002)$. Duża powierzchnia oparzenia, powyżej $20 \%$ TBSA, stwierdzona została tylko u 6\% z grupy I, oraz u $13 \%$ pacjentów z grupy II.

U dzieci z obu przedziałów czasowych oparzenia najczęściej obejmowały kończyny górne (NS), a w latach 2006-2010 także przód tułowia ( $\mathrm{p}=0,00000)$. Oparzenia kończyn dolnych częściej występowały w latach 1985-1988 i dotyczyły 43\% pacjentów, a w latach 2006-2010 tylko 28\% (p = 0,00000). Oparzenie głowy stwierdzono u $28 \%$ dzieci w pierwszym przedziale czasowym i odpowiednio $42 \% \mathrm{w}$ drugim przedziale czasowym ( $p=0,00000)$. Oparzenie okolicy krocza dotyczyło odpowiednio $9 \%$ i $5 \%$ pacjentów $(\mathrm{p}=0,00102)$ - rycina 4 .

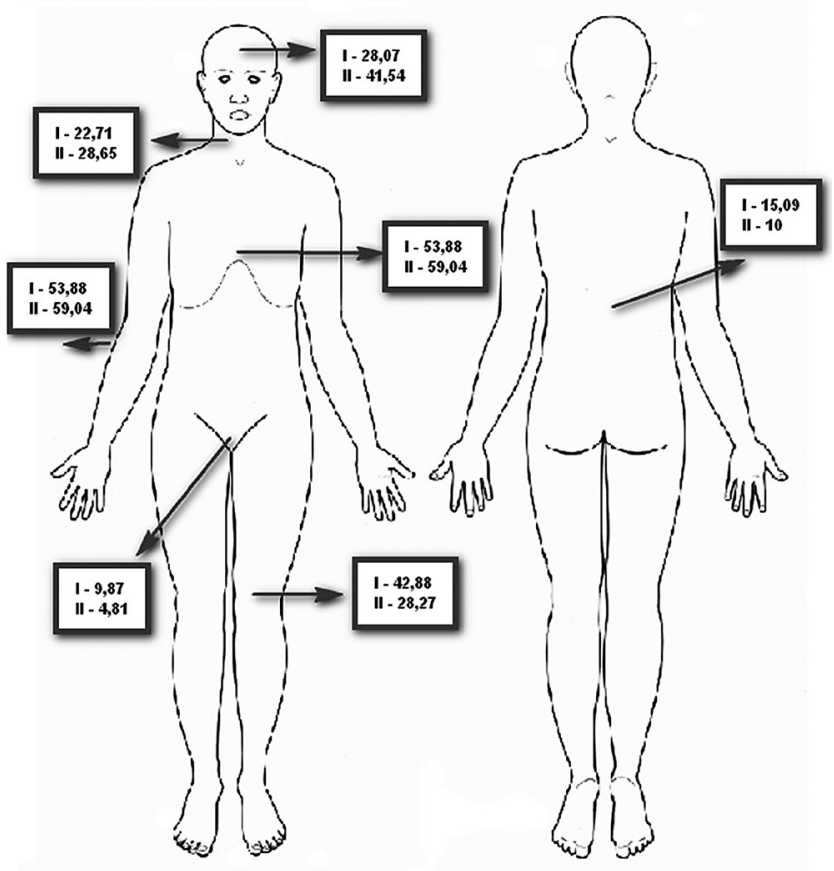

RYCINA 4. Procentowa lokalizacja oparzonych obszarów ciała u dzieci ( I - 1985-1988; II - 2006-2010) 
TABELA 1. Głębokość oparzenia u hospitalizowanych pacjentów

\begin{tabular}{|c|c|c|c|}
\hline \multirow[b]{2}{*}{ Lata } & \multicolumn{3}{|c|}{ Głębokość oparzenia } \\
\hline & $\begin{array}{c}\text { powierzchowne } \\
\text { (\%) }\end{array}$ & $\begin{array}{c}\text { głębokie } \\
\text { niepetnej } \\
\text { grubości (\%) }\end{array}$ & $\begin{array}{l}\text { głębokie pełnej } \\
\text { grubości (\%) }\end{array}$ \\
\hline 1985-1988 & 9,75 & 53,67 & 36,58 \\
\hline $2006-2010$ & 12,96 & 39,26 & 47,48 \\
\hline
\end{tabular}

W obydwu porównywanych okresach czasu najczęściej hospitalizowano dzieci z oparzeniami głębokimi niepełnej i pełnej grubości skóry. W latach 1985-1988 częściej były to dzieci z oparzeniami głębokimi niepełnej grubości skóry (54\% vs 39\%; p < 0,001), a w latach 2006-2010 z oparzeniami głębokimi pełnej grubości skóry (37\% vs 48\%; NS) - tabela 1.

\section{Pierwsza pomoc}

Z wywiadu wynika, że bezpośrednio po oparzeniu rodzice/ opiekunowie stosowali różnorodne metody udzielania pierwszej pomocy. Ranę oparzeniową schłodzono tylko u 26\% dzieci w grupie I i u $39 \%$ w grupie II ( $p<0,001)$.

W latach 1985-1988 bezpośrednio po oparzeniu u 173 (24,4\%) dzieci do miejscowego „zabezpieczenia” rany rodzice/opiekunowie używali różnych środków. Były to środki farmaceutyczne, spożywcze i chemiczne. W latach 2006-2010 postępowanie takie obserwowano rzadziej, bo tylko u 13 (2,5\%) dzieci.

W obu badanych grupach dzieci z oparzeniem ciężkim w ponad 21\% przypadków były przewożone do szpitala przez samych opiekunów, bez prawidłowego zabezpieczenia miejscowego i ogólnego.

Dzieci hospitalizowane z oparzeniem zastarzałym w obu badanych grupach stanowiły po 7\%, z czego ciężko oparzonych w latach $1985-1988$ było 5,77\%, a w latach 2006-2010 - 0,83\%.

\section{Leczenie szpitalne}

Średni czas hospitalizacji dzieci z oparzeniem skóry w grupie I wynosił 18 (1-241) dni, a w grupie II - 9 (1-42) dni ( $p<0,001)$.

W obu badanych grupach stwierdzono istotny wpływ głębokości oparzenia na częstość stosowania leczenia operacyjnego ( $\mathrm{p}<0,001$ ). Najczęściej dotyczyło dzieci z oparzeniem głębokim pełnej grubości skóry ( $80 \%$ vs $85 \%$; NS), rzadziej z oparzeniem głębokim niepełnej grubości skóry (30\% vs 28\%; NS), sporadycznie z oparzeniem powierzchownym (1\% vs $4 \%$; NS).

Średni termin wykonania przeszczepu skóry różnił się istotnie pomiędzy grupą I i II (19 dni vs 7,5 dnia; p < 0,001). W grupie I przeszczepy wykonywano 1.-71. doby od chwili oparzenia, a w grupie II znacznie wcześniej, bo 3.-30. doby.

W obu analizowanych przedziałach czasowych nie stwierdzono ciężkich powikłań pod postacią posocznicy, zespołu MODS i zgonu pacjenta. Obserwowano natomiast nieliczne powikłania chirurgiczne (zakażenie rany, brak wgojenia przeszczepu) oraz częste zakażenia ogólne wewnątrzszpitalne (zakażenie górnych i dolnych dróg oddechowych oraz nieżyt żołądkowo-jelitowy). W trakcie leczenia oparzeń powikłania wystąpiły u $51 \%$ dzieci z grupy I i u $20 \%$ z grupy II $(p<0,001)-$ rycina 5 .

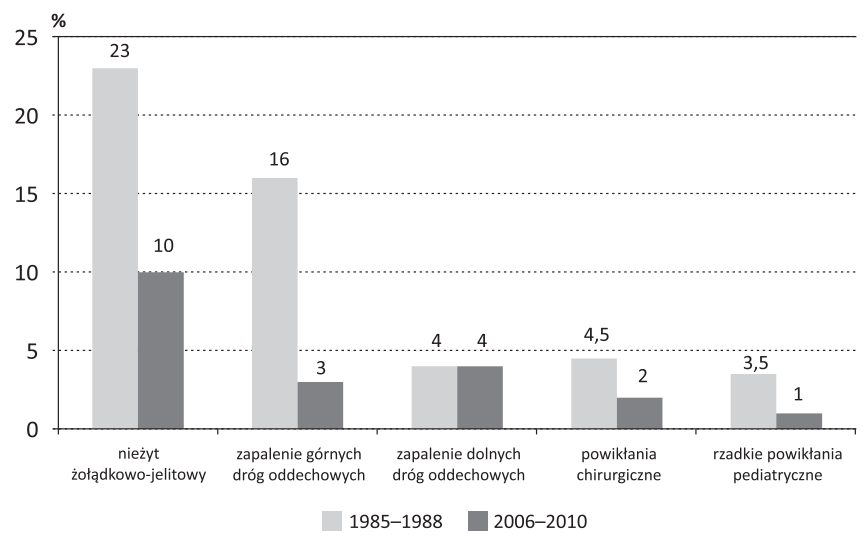

RYCINA 5. Częstość i rodzaj powikłań leczenia oparzeń

\section{DYSKUSJA}

Przedstawione badania pochodzą z ośrodka w województwie zachodniopomorskim specjalizującego się w leczeniu oparzeń u dzieci. W Polsce liczba ośrodków oparzeniowych dla dzieci jest niewielka, dlatego część przypadków jest leczona na oddziałach chirurgii dziecięcej.

Badania innych autorów, podobnie jak własne, wskazują na obserwowany w ciągu lat istotny spadek liczby pacjentów hospitalizowanych z powodu oparzeń. Jest on stwierdzany w każdej grupie wiekowej, a wśród dzieci sięga nawet 50\% $[2,3,4]$.

$\mathrm{Z}$ analizy badanego materiału wyłania się model oparzonego dziecka poddanego hospitalizacji, niezmienny na przestrzeni lat, spójny z wynikami prac innych autorów [2, 6]. Jest nim przede wszystkim chłopiec (1,7-krotnie częściej) w wieku do 3 lat oparzony gorącym płynem. Najczęściej do wypadku dochodzi w domu, przy braku należytej opieki osób dorosłych. Małe ofiary oparzeń, które w tym wieku są nadmiernie ruchliwe, ciekawe, próbują naśladować w codziennych czynnościach osoby dorosłe, ze względu na ograniczenia rozwojowe nie potrafią same dokonać prawidłowej oceny zagrożeń występujących w swoim najbliższym otoczeniu. Sięgają po gorące naczynie, stąd najczęściej zmiany oparzeniowe lokalizują się w obrębie kończyn górnych i tułowia.

Analizując ciężkość oparzenia, dokonano oceny rozległości powierzchni oparzonej. Posłużono się tablicami Lunda i Browdera, które - ze względu na zmieniające się w każdym wieku proporcje ciała dziecka - najdokładniej określają procentowy udział powierzchni oparzonej w stosunku do całej powierzchni ciała [7]. Z analizowanego materiału wynika, że w dużym odsetku hospitalizowanych dzieci powierzchnia oparzenia nie przekraczała 10\% TBSA. Podobne wyniki otrzymali inni autorzy. W badaniach autorów niemieckich oparzenia poniżej 10\% TBSA stanowiły $83 \%$, w badaniach tureckich $74 \%$, chińskich - 55,4\%, a w australijskich aż 90\% [8, 9, 10, 11].

Kolejnym kryterium oceny było określenie głębokości oparzenia. Puchała podaje, że w $80 \%$ populacji pediatrycznej występują oparzenia o niepełnej grubości skóry zajmujące niewielką powierzchnię [12]. Podobne wyniki otrzymali autorzy 
z południowo-wschodniej Turcji, gdzie oparzenia II stopnia stanowiły 92,6\% hospitalizowanych [13]. W materiale własnym w obu badanych grupach przeważały dzieci z oparzeniami głębokimi niepełnej i pełnej grubości skóry. W latach 1985-1988 stanowiły one 90\%, a w latach 2006-2010 nieco mniej, bo $87 \%$ badanych. Prawdopodobnie można to tłumaczyć tym, że w odróżnieniu od innych ośrodków, w regionie Pomorza Zachodniego dzieci z oparzeniami powierzchownymi w większości były leczone i kontrolowane ambulatoryjnie.

Sposób udzielania pierwszej pomocy przez opiekunów oparzonych dzieci nie zawsze zgadza się z wytycznymi opracowanymi przez specjalistów. Najważniejszym elementem postępowania miejscowego jest schładzanie oparzonej powierzchni. Na podstawie analizy badań własnych stwierdzono, że ten sposób postępowania był rzadko stosowany w obu grupach. Prawidłowo przeprowadzone chłodzenie powierzchni oparzonej jest bardzo istotnym elementem postępowania, ponieważ powoduje zmniejszenie dolegliwości bólowych oraz zahamowanie konwersji głębokości rany, co przyspiesza gojenie i zapobiega powstawaniu późniejszych blizn [14]. Porównywalnie niskie wyniki wykonywania $\mathrm{w}$ ramach pierwszej pomocy przedmedycznej schładzania rany oparzeniowej na poziomie $27,17 \%$ otrzymali autorzy wietnamscy [15]. Inni podają o wiele wyższy odsetek dzieci, u których dokonano schładzania rany oparzeniowej $[16,17]$.

Z analizy materiału własnego wynika, że w latach 19851988 na miejscu wypadku rodzice/opiekunowie stosowali różnorodne „metody” udzielania pierwszej pomocy, poczynając od smarowania rany oparzeniowej maściami i innymi środkami medycznymi (pantenol, pyoctanina, rivanol, altacet, kwas borny), poprzez stosowanie środków spożywczych (oliwa, masło, mąka, jajko, mleko, sól, proszek do pieczenia), aż do używania na rany spirytusu, denaturatu, mydła, pasty do zębów oraz moczu. Prawdopodobnie stosowanie tych środków wynikało z wcześniej zakorzenionych, wielowiekowych zasad leczenia ran oparzeniowych za pomocą metod medycyny naturalnej. Stosowano środki pochodzenia roślinnego i zwierzęcego, które miały za zadanie osuszyć ranę i doprowadzić do powstania strupów, w większości jednak infekowały ją i pogłębiały oparzenie. Zacierały również obraz kliniczny, co prowadziło do trudności z jego prawidłową interpretacją $[18,19]$.

W latach 2006-2010 metody medycyny naturalnej stosowano znacznie rzadziej, co może świadczyć o lepszej edukacji rodziców i opiekunów dzieci na temat postępowania po oparzeniu skóry. O obserwowanym obecnie rzadkim stosowaniu środków medycyny naturalnej piszą także Mierzwa i wsp. [20].

Wytyczne ustanowione przez specjalistów zajmujących się tematyką opieki nad oparzonymi pacjentami jasno definiują zasady udzielania pomocy przedszpitalnej, w tym transportu medycznego, którym powinni podlegać poszkodowani. Wynika z nich, że fachowa pomoc medyczna powinna być udzielona już na miejscu wypadku. Oparzone dziecko, w zależności od odległości, powinno być przewiezione albo do oparzeniowego ośrodka specjalistycznego, albo do najbliższego oddziału chirurgicznego [21]. Jak wynika z przeprowadzonych badań, warunki te nie zawsze były spełnione, zwłaszcza wówczas, gdy opiekunowie nie wzywali na miejsce wypadku fachowej pomocy medycznej. Na uwagę zasługuje fakt, że w obu badanych grupach ponad $21 \%$ dzieci samodzielnie dowiezionych przez opiekunów to pacjenci ciężko oparzeni.

W materiale własnym po 7\% pacjentów hospitalizowanych w obydwu badanych grupach stanowiły dzieci z oparzeniami zastarzałymi, co świadczy o opóźnionym transporcie dziecka do szpitala, zwykle po upływie 24 godz. 0 jeszcze wyższym odsetku dzieci hospitalizowanych z oparzeniem zastarzałym (90\%) donoszą autorzy z Tanzanii oraz Senegalu, gdzie większość dzieci trafiała do szpitala z opóźnieniem, średnio w 33 godz. od urazu, czyli od 2 godz. do 7 dni od zdarzenia [22, 23].

Sposób miejscowego leczenia oparzeń u dzieci jest uzależniony od stopnia uszkodzenia kolejnych warstw skóry. Niezależnie od rodzaju wybranego leczenia zastosowane metody mają za zadanie nie dopuścić do rozwoju zakażenia w ranie oraz spowodować jak najszybsze odtworzenie uszkodzonej skóry, z dbałością o wygląd kosmetyczny miejsca oparzonego [24].

Oparzenia powierzchowne, w których samoistnie może dojść do regeneracji naskórka od dna rany, leczy się zachowawczo; w zależności od uszkodzonej okolicy ciała stosuje się metodę otwartą lub zamkniętą. Obecnie kanonem leczenia głębokich oparzeń jest natychmiastowe oczyszczenie skóry oraz wczesne wycięcie martwicy i pokrycie powierzchni autoprzeszczepami lub materiałami biologicznymi albo tworzywami zastępującymi skórę [25]. W materiale własnym w przypadku oparzeń głębokich nie obserwowano różnic w częstości wykonywanych zabiegów operacyjnych. W latach 80. XX w. przeszczepy skóry wykonywano późno, najczęściej pomiędzy 14. a 22. dobą od urazu, średnio w 19. dobie. Obecnie preferuje się szybsze zamykanie oparzeń głębokich, najczęściej pomiędzy 4. a 9. dobą, średnio w 7,5 dnia.

Wybór sposobu leczenia oparzeń głębokich ewoluował w świadomości badaczy końca XX i początku XXI w. Ukazywały się różne prace przemawiające za lub przeciw obranym metodom. Autorzy preferujący sposób zachowawczego leczenia wskazywali na zmniejszone ryzyko wystąpienia powikłań podczas znieczulenia i samej operacji. Udowadniali, że nie ma różnic w wynikach leczenia pomiędzy zastosowanymi metodami. Jednocześnie potwierdzali, że takie postępowanie wydłuża czas hospitalizacji (16-69 dni), co z różnych powodów może być niekorzystne dla pacjenta [26, 27].

Przeciwnicy leczenia konserwatywnego wykazali, że wczesne chirurgiczne zamykanie ran, do 48 godz. od urazu, zmniejsza ryzyko zainfekowania rany, skraca czas hospitalizacji, prowadzi do lepszego wyniku funkcjonalnego i kosmetycznego [28, 29, 30, 31].

Długość hospitalizacji zależy od ciężkości oparzenia oraz od obranej metody leczenia. Potwierdzeniem tej tezy są wyniki badań, które otrzymali Still i wsp. oraz Owczarek i wsp. [32, 33]. $\mathrm{Z}$ analizy materiału własnego wynika, że w ostatnich 20 latach średni czas hospitalizacji dzieci z oparzeniem skóry skrócił się 2-krotnie i obecnie dla dzieci z oparzeniem lekkim wynosi 7 dni, średnim - 8 dni i ciężkim - 14 dni.

Żelanowska i Sukiennicki, analizując oparzenia u dzieci do 3. r.ż., stwierdzili, że na długość hospitalizacji ma wpływ 
rozległość oparzenia, a przede wszystkim głębokość rany oparzeniowej. Ponad połowa ich badanych (57,5\%) miała oparzenia powierzchowne i była leczona do $10 \mathrm{dni}$ [34]. Podobne dane przedstawili Mierzwa i wsp. Dzieci z oparzeniami powierzchownymi do $10 \%$ TBSA hospitalizowane były 5-11 dni, natomiast z oparzeniem IIb i 10-20\% TBSA pozostawały w szpitalu 18-23 dni [20].

Mikołajczyk i wsp. analizowali oparzenia u niemowląt. Stwierdzili, że czas leczenia zachowawczego wynosił średnio 8,8 (2-25) dnia, a leczenia operacyjnego - 17,6 dnia [35].

Zakażenia są głównym czynnikiem doprowadzającym do powikłań w trakcie leczenia oparzonych dzieci, najczęściej Pseudomonas aeruginosa, Acinetobacter species i Escherichia coli [13]. Dochodzi do nich poprzez zakażenie rany oparzeniowej lub zakażenia odcewnikowe z centralnego dostępu naczyniowego [36]. W materiale własnym zakażenia rany występowały bardzo rzadko, bo u 0,6\% dzieci, wyłącznie w grupie I.

Śmiertelność z powodu oparzeń u dzieci uległa znacznemu obniżeniu. Autorzy wskazują na niski wiek pacjentów, dużą rozległość obrażeń, powikłania septyczne i niewydolność oddechową jako najczęstsze przyczyny zgonów [37, 38]. W materiale własnym nie odnotowano zgonów.

\section{WNIOSKI}

1. Na Pomorzu Zachodnim w ostatnich 25 latach znacznie obniżyła się częstość hospitalizacji oparzonych dzieci, co prawdopodobnie można wiązać ze wzrostem świadomości społecznej dotyczącej znajomości zagrożeń. Na przestrzeni lat nie zmienił się wzór najczęstszych oparzeń u dzieci - nadal uraz termiczny dotyczy dzieci najmłodszych i następuje w wyniku kontaktu z gorącym płynem, co świadczy o niedostatecznej opiece osób dorosłych nad dziećmi.

2. Znajomość zasad udzielania pierwszej pomocy przez opiekunów dzieci nadal jest niedostateczna. Może to świadczyć o braku skuteczności kampanii profilaktycznych. Pomimo polepszenia się profesjonalnych warunków transportu oparzonych dzieci do szpitala, nadal utrzymuje się niekorzystne zjawisko przewożenia ciężko oparzonych pacjentów własnym środkiem transportu przez samych rodziców.

3. W ostatnich latach, wraz z utworzeniem centrów oparzeniowych nastawionych na wielospecjalistyczne leczenie, znacznie wzrosły możliwości leczenia ciężko oparzonych dzieci. Nadal jednak z powodu bagatelizowania problemu przez rodziców aż 7\% dzieci bezpośrednio po oparzeniu nie uzyskuje żadnej pomocy.

4. Na przestrzeni ostatnich 25 lat na Pomorzu Zachodnim średni czas hospitalizacji oparzonych dzieci uległ 2-krotnemu skróceniu. Jest to następstwem przede wszystkim wcześniejszego przeprowadzania przeszczepów skóry oraz spadku częstości powikłań.

5. Na przestrzeni ostatnich 25 lat wśród ludności zamieszkującej na Pomorzu Zachodnim wzrosła wiedza o zasadach opieki nad dziećmi z oparzeniem skóry. Nadal jednak nie jest ona zadowalająca. W społeczeństwie należy rozpowszechnić informacje o zasadach udzielania pierwszej pomocy przedmedycznej, konieczności oceny każdego oparzenia w ośrodku specjalistycznym oraz zasadach transportu oparzonych.

\section{PIŚMIENNICTWO}

1. Hewitt A, Macarthur C, Raina P.S. The role of evidence in public health policy: an example of linkage and exchange in the prevention of scald burns. Health Policy 2007;3(2):59-66.

2. Peden M, Oyegbite K, Ozanne-Smith J, Hyder AA, Branche. C, Fazlur Rahman AKM, et al., editors. World report on child injury prevention. Geneva: World Health Organization; 2008. whqlibdoc.who.int/publications/2008/9789241563574_eng.pdf?ua=1 (25.01.2016).

3. Albertyn R, Bickler SW, Rode H. Paediatric burn injuries in Sub Saharan Africa - an overview. Burns 2006;32(5):605-12.

4. Chrapusta-Klimeczek A, Puchała J. Farmakoekonomika leczenia oparzeń u dzieci w aspekcie stosowania nowoczesnych opatrunków specjalistycznych. Leczenie Ran 2007;4(2):39.

5. Poulos RG, Hayen A, Chong SS, Finch CF. Geographic mapping as a tool for identifying communities at high risk of fire and burn injuries in children. Burns 2009;35(3):417-24.

6. Drago DA. Kitchen scalds and thermal burns in children five years and younger. Pediatrics 2005;115(1):10-6.

7. Lund CC, Browder NC. The estimation of areas of burns. Surg Gynecol Obstet 1944;79:352-8.

8. Schneider C. Klinische und psychologische Aspekte bei brandverletzten Kindern. Eine Langzeitstudie des Verbrennungszentrums [dissertation]. Aachen: RWTH Aachen Univ. - Medizinische Fakultät; 2002.

9. Uygur F, Sahin C, Duman H. Analysis of pediatric burns in a tertiary burns center in Istanbul, Turkey. Eur J Pediatr Surg 2009;19(3):174-8.

10. Zhou B, Zhou X, Ouyang LZ, Huang XY, Zhang PH, Zhang MH, et al. An epidemiological analysis of paediatric burns in urban and rural areas in south central China. Burns 2014;40(1):150-6.

11. Duke J, Wood F, Semmens J. A study of burn hospitalizations for children younger than 5 years of age: 1983-2008. Pediatrics 2011;127(4):971-7.

12. Puchała J, Spodaryk M, Jarosz J, editors. Oparzenia u dzieci od urazu do wyleczenia. Kraków: Wydawnictwo Uniwersytetu Jagiellońskiego; 1998. p. 12.

13. Tekin R, Yolbaş I, Selçuk CT, Güneş A. An evaluation of pediatric burn patients over a 15-year period. Turk J Trau Emerg Surg 2012;18(6):514-8.

14. Davies JW. Prompt cooling of burned areas: a review of benefits and the effector mechanisms. Burns Incl Therm Inj 1982;9(1):1-6.

15. Lam NN, Dung NT. First aid and initial management for childhood burns in Vietnam - an appeal for public and continuing medical education. Burns 2008;34(1):67-70.

16. Cuttle L, Kravchuk O, Wallis B, Kimble RM. An audit of first-aid treatment of pediatric burns patients and their clinical outcome. J Burn Care Res 2009;30(6):1028-34.

17. Brudvik C, Hoem EL, Luggenes B, Vindenes H. Burn injuries in children. Tidsskr Nor Legeforen 2011;131:20-3.

18. Pinnegar MD, Pinnegar FC III. History of burn care - a survey of important changes in the topical treatment of thermal injuries. Burns 1986;12(7): 508-17.

19. Pinnegar MD, Mahler D. Folklore-medicine and burns. Burns 1980;7(4): 275-85.

20. Mierzwa W, Porębska A, Hudzik D, Pawlik K. Oparzenia u noworodków i niemowląt leczonych na Oddziale Chirurgii Dziecięcej w Kielcach w latach 1994-1998. Dermatol Klin Zabieg 1999;1(2):66-70.

21. Allison K, Porter K. Consensus on the prehospital approach to burns patient management. Emerg Med J 2004;21(1):112-4.

22. Chalya PL, Mabula JB, Dass RM, Giiti G. Pattern of childhood burn injuries and their management outcome at Bugando Medical Centre in Northwestern Tanzania. BMC Res Notes 2011;9;4:485.

23. Diop-Ndoye M, Bodjona JP, Diouf E, Beye MD. Management of thermal severe burns in children in Le Dantec University Teaching Hospital. Dakar Med 2005;50(3):194-7.

24. Kaźmierski M, Mańkowski P, Jankowski A. Miejscowe leczenie rany oparzeniowej u dzieci. Twój Mag Med - Chirurgia 2003;3(108):86-97. 
25. Jethon J, Strużyna J. Leczenie oparzeń. Med Prakt Chir 2005;1:150-6.

26. De Mey A, Deraemaecker R, Dereere R, Deconinck P. Conservative treatment of 725 burned children hospitalized in 10 years. Burns 1986;4(12):297-300.

27. Gore D, Desai M, Herndon DN, Abston S, Evans EB. Comparison of complications during rehabilitation between conservative and early surgical management in thermal burns involving the feet of children and adolescents. J Burn Care Rehabil 1988;9(1):92-5.

28. Mahler D, Benmeir P, Ben Yakar Y, Greber B. Treatment of the burned hand: early surgical treatment (1975-85) vs. conservative treatment (1964-74). A comparative study. Burns Incl Therm Inj 1987;13(1) 45-8.

29. Lindell-Iwan L. Burns in children with special reference to the benefits of primary excision and immediate grafting. Ann Chir Gynaecol 1980;69(5):202-7.

30. Gray DT, Pine RW, Harnar TJ, Marvin JA. Early surgical excision versus conventional therapy in patients with 20 to 40 percent burns. A comparative study. Am J Surg 1982;144(1):76-80.
31. Xiao-Wu W, Herndon DN, Spies M, Sanford AP, Wolf SE. Effects of delayed wound excision and grafting in severely burned children. Arch Surg 2002;137(9):1049-54.

32. Still JM Jr, Law EJ, Belcher K, Thiruvaiyarv D. Decreasing length of hospital stay by early excision and grafting of burns. South Med J 1996;89(6):578-2.

33. Owczarek A, Czarnecki P, Frasunkiewicz A. Analiza oparzeń u dzieci w latach 1991-95. Roczniki Oparzeń 1996-97;7/8:173-6.

34. Żelanowska S, Sukiennicki A. Ocena leczenia oparzeń u dzieci w wieku do 3 lat na Oddziale Chirurgii Dziecięcej w Ostrowie Wlkp. w latach 1990-1996. Roczniki Oparzeń 1996-97;7/8:167-71.

35. Mikołajczyk A, Porębska A, Łuczyński R. Analiza oparzeń u dzieci do 1. roku życia. Roczniki Oparzeń 1996-97;7/8:163-6.

36. Rodgers GL, Motensen J, Fischer M, Lo A. Predictors of infectious complications after burn injuries in children. Pediatr Infect Dis J 2000;19:990-5.

37. Bowman SM, Aitken ME, Maham SA, Sharar SR. Trends in hospitalizations associated with pediatric burns. Inj Prev 2011;17(3):166-70.

38. Linares HA. A report of 115 consecutive autopsies in burned children: 1966-80. Burns Incl Therm Inj 1982;8(4):263-70. 